ENTREPRENEURSHIP AND SUSTAINABILITY ISSUES

ISSN 2345-0282 (online) http://jssidoi.org/jesi/

2020 Volume 7 Number 4 (June)

http://doi.org/10.9770/jesi.2020.7.4(40)

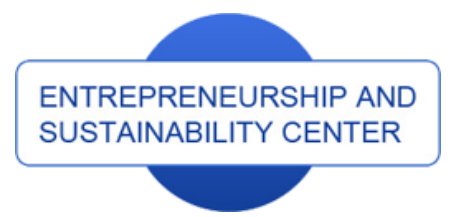

Publisher

http://jssidoi.org/esc/home

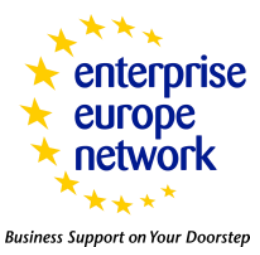

CASPA

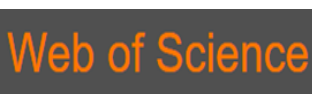

1) Clarivate

\title{
THE INTRODUCTION OF PECTIN-CONTAINING FOODS FOR THE COMPETITIVENESS OF ENTERPRISES
}

\author{
Maigul Zhalelovna Kizatova ', Sanavar Tuglukovna Azimova ${ }^{2}$, Galiya Kuandykovna Iskakova ${ }^{3}$, \\ Farrukh Abdigapurovich Makhmudov ${ }^{4}$, Almira Anuarbekovna Bekturganova ${ }^{5}$ \\ ${ }^{1}$ Kazakh National Medical University, Almaty, Tole bi, 94, The Republic of Kazakhstan \\ 2,3,4 Almaty Technological University, Almaty, Kazakhstan, Tole bi, 10, The Republic of Kazakhstan \\ ${ }^{5}$ Kazakh University of Technology and Business, Astana, st. Mukhametkhanova, 37A, The Republic of Kazakhstan \\ E-mails: ${ }^{1}$ kizatova@mail.ru; ${ }^{2}$ sanaazimova@mail.ru; ${ }^{3}$ iskakova-61@mail.ru; ${ }^{4}$ f.makhmudov@orbis-kz.com; \\ $5 \underline{1968 a l 1 @ m a i l . r u}$
}

Received 15 January 2020; accepted 15 April 2020; published 30 June 2020

\begin{abstract}
The article discusses scientific findings of development new innovative products of high nutrition value. Specifically, the article presents the results of economic efficiency in the production of bread and confiture enriched with pumpkin pectin. The cost of 1 ton of bread enriched with pumpkin pectin in an amount of $0.5 \%$ exceeded $14.0 \%$, compared with a control batch without pectin. The cost of $1 \mathrm{~kg}$ of confiture with pumpkin pectin (1.0\%) is lower by $9 \%$ of the cost of the control sample due to the reduction in cooking time, which saves energy consumption by $25 \%$ and the amount of sugar by $7.5 \%$. The obtained results can be used for introduction of innovative pectincontaining products and enhancing competitiveness of food producing enterprises.
\end{abstract}

Keywords: economic and social efficiency; innovative food products; pectin-containing bread; confiture

Reference to this paper should be made as follows: Kizatova, M.Zh., Azimova, S.T., Iskakova, G.K., Makhmudov, F.A., Bekturganova, A.A. 2020. The introduction of pectin-containing foods for the competitiveness of enterprises. Entrepreneurship and Sustainability Issues, 7(4), 3191-3199. https://doi.org/10.9770/jesi.2020.7.4(40)

JEL Codes: O13, P42

\footnotetext{
* The research was carried out within the framework of the performance-based grant budgeting for 2018-2020 by the Ministry of Education and Science of the Republic of Kazakhstan under the Program "Creating Healthy Foods with Functional Orientation Based on Agricultural Raw Materials".
} 


\section{ENTREPRENEURSHIP AND SUSTAINABILITY ISSUES}

ISSN 2345-0282 (online) http://jssidoi.org/jesi/

2020 Volume 7 Number 4 (June)

http://doi.org/10.9770/jesi.2020.7.4(40)

\section{Introduction}

The competitiveness of various business entities is an urgent topic of economic research. To increase the competitiveness of food enterprises, important conditions are: technological -innovation in the field of industrial technology, assortment - the creation of new food products, marketing, as well as the creation of innovative infrastructure. The features of technological innovations at the food industry include: the development and implementation of innovative technologies for processing and storage of agricultural products, characterized by the most useful output of a new range of finished products.

The level of development of the food industry determines the viability of the population and is an important part of the food safety of the state. This industry, consisting of more than 20 industries, produces almost all food products necessary for the population, including special products (Almaty's contribution to food production in the country, 2019).

In modern conditions of development of scientific and technological progress, more and more attention is paid to improving the structure and quality of nutrition as one of the main factors in a healthy lifestyle. Many diseases of civilization, such as obesity, atherosclerosis are directly related to malnutrition, which is expressed in increased consumption of foods with high energy value and inadequate consumption of foods containing biologically active nutrients: vitamins, dietary fiber, pectin and others. The solution to this problem is mostly connected with the introduction of new food formulations with natural additives. With using additives of plant origin that increase the nutritional value of food products, it is also necessary to take into account the influence that they have on their quality, since the modern consumer, in a competitive environment in the food manufacturing market, pays considerable attention to their quality.

One of the important functional additives is dietary fiber, which has certain physiological properties in the prevention and treatment of a number of diseases. Pectins of various origin are also considered dietary fiber. Pectins have sorption properties based on the interaction of their molecules with heavy and radioactive metal ions due to the presence of free carboxyl groups. Therefore, the inclusion of pectin in the diet of people in an environment contaminated with radionuclides and in contact with heavy metals is relevant (Gavrilenkov, 2006; Kostyuk, 2005).

In recent years, in our country and abroad, scientists have been actively searching for substances that can truly protect the health of people working in hazardous industries, residents of large cities and large industrial centers, suffering from increased environmental pollution. Naturally preferred are detoxifiers of natural origin (Kostyuk, 2005; AlmovaI et al., 2014).

Today, heavy metal intoxications are the leading among the harmful factors of production, this is especially evident in enterprises of the mining industry for the extraction of non-ferrous metals, metallurgical and chemical industries (lead-zinc, copper smelters, enterprises for the production of polyvalent metals). In addition, heavy metal pollution of atmospheric air, soil, water in the vicinity of such industries, near major highways and in large metropolitan areas of the country poses a risk of their entry into the adult population and children living in these regions (Azimova et al., 2016; Ecology and health of the nation. Collection, 2016; Alibaeva et al., 2015; Moumen et al., 2019).

One of the priorities of the state policy of Kazakhstan in the field of healthy nutrition of the population is the creation of innovative food products using physiologically functional ingredients that can prevent the effects of negative environmental factors on the human body. The solution to this problem is possible by expanding the range of products containing pectins, which occupy a leading position among effective biological sorbents and possess immunomodulating, antioxidant, antibacterial and other effects. 


\section{ENTREPRENEURSHIP AND SUSTAINABILITY ISSUES}

ISSN 2345-0282 (online) http://jssidoi.org/jesi/

2020 Volume 7 Number 4 (June)

http://doi.org/10.9770/jesi.2020.7.4(40)

\section{Relevance}

The use of pectins in the food industry has reached enormous proportions. Pectins are used as an additive to medicinal varieties of bakery and pasta; in bakery - for baking non-stale varieties of bread (Noreen et al., 2017; Grassino et al., 2018; Azimova et al., 2017; Lara-Espinoza et al., 2018; Martins et al., 2017; Babich et al., 2017). Improving the quality of bread with the addition of low-etherified pectin (NE) is associated with the presence in its molecule of a greater number of free carboxylic groups than that of highly etherified (CE) pectin. These groups are reactive, and, actively interacting with the components of the dough, form a large number of compounds, affecting the properties and quality of bread.

A change in the storage process of the structural and mechanical properties of bread crumb with the addition of pectin in an amount of $0.05-1.0 \%$ by weight of flour indicates that bread with the addition of pectin is stale 1.041.9 times slower than bread without pectin, which is extremely important for increasing the period of implementation of bakery products in trade organizations (Janabi et al., 2017; Murzahmetova et al., 2015).

Preserving vegetables and fruits by freezing, drying, boiling using sugar, antiseptics, pasteurization, sterilization has a number of disadvantages, the main of which is a decrease in the nutritional value of the product, loss of the original taste and aroma. Therefore, the preservation of the native properties of berries and fruits and the development of confiture with the addition of pectin on their basis is an urgent task. Due to their complexforming, gel-forming, emulsifying properties, pectins are used in the production of confectionery, canned goods, medical preparations, in bakery, and therapeutic and preventive nutrition (Donchenko, 2000; Belousova, Donchenko, 2019).

It was also found that the introduction of pectins in the dough affects the biological, colloidal and microbiological processes of dough preparation. Due to its special physico-chemical properties, pectin affects the shelf life of the freshness of bread, gingerbread, cookies, biscuits, muffins. Studies in this area show that this process is almost 2 times slower.

Thus, the use of pectins makes it possible to increase the shelf life of bread, as a result of which the return of products from trade organizations back to production is reduced, which is economically beneficial for the bakery industry. The economic efficiency of the production of confiture using pectin as a thickener will allow energy savings by reducing the duration of boiling and the amount of sugar added (Azimova et al., 2018).

It is worth noting that in the context of rapidly growing competition, with the constant and dynamic development of the business, it is necessary to radically revise modern approaches to the essence and specifics of innovation (Melnikov et al, 2019). The US Department of Commerce has estimated the size of the domestic market for environmentally friendly products. Even during the economic downturn in 2008-2011, in the United States every three out of four companies reported an increase in sales of environmentally friendly products relative to ordinary categories of products, $49 \%$ of which estimated growth by more than $10 \%$. Obviously, what is good for buyers can be beneficial for business as well. In the USA, according to a survey, $79 \%$ of companies confidently agreed that the provision of environmentally friendly products and services gives their business a competitive advantage. This study reveals the economic and social importance of introducing innovative food products in the food industry of Kazakhstan using the example of individual enterprises - one of the large bakery "Almatynan» limited liability partnership (LLP) and fruit and vegetable factory «SDiK» (LLP) with using pumpkin pectin to create pectin-containing bread and confiture.

The purpose of this study is to assess the economic and social effectiveness of food enterprises based on the creation and implementation of innovative food products using pumpkin pectin. 


\section{ENTREPRENEURSHIP AND SUSTAINABILITY ISSUES}

ISSN 2345-0282 (online) http://jssidoi.org/jesi/

2020 Volume 7 Number 4 (June)

http://doi.org/10.9770/jesi.2020.7.4(40)

\section{Results and its discussion}

In the production conditions of the bakery "Bakery factory Almatynan"production tests of bread made from wheat flour of the first grade with pumpkin pectin were conducted. Based on the numerous results of experimental data, we have developed the optimal bread formulation using pumpkin pectin $0.5 \%$. To use pumpkin pectin in the production of bread, it was considered correct to calculate the economic efficiency of introducing such bread. The economic effect of production is expressed in the amount of profit received from the sale of the developed product. When calculating the costing, all cost items were calculated on the base case (without the use of pumpkin pectin) and on the developed variety of bread with pumpkin pectin.

Calculation of the main raw materials - flour grade 1

The amount of flour was determined for the production of 1 ton of bread: amount of flour $=$ (production / yield) $\mathrm{x}$ $100=(1000 \mathrm{~kg} / 138 \%) \times 100 \%=724.6 \mathrm{~kg}$. The output rate means the minimum allowable yield of $100 \mathrm{~kg}$ of flour. The yield of bread is set on flour with a certain "base" humidity. The base moisture content of flour is $14.5 \%$ [22].

When using $0.5 \%$ pumpkin pectin, the yield of bread increased by $8.7 \%$ in comparison with the control (table 1), which corresponds to a decrease in the consumption of wheat flour by $8.7 \%$ to produce 1 ton of bread.

Table 1. The effect of pectin content on the volume of bread

\begin{tabular}{|c|c|c|c|c|c|c|}
\hline \multirow[t]{2}{*}{ Indicator } & \multirow[t]{2}{*}{ Control } & \multicolumn{5}{|c|}{ The content of introduced pectin, $\%$} \\
\hline & & 0,25 & 0,5 & 0,75 & 1,0 & 1,25 \\
\hline $\begin{array}{l}\text { The volume of } \\
\text { bread, } \mathrm{cm}^{3}\end{array}$ & 2190 & 2280 & 2380 & 2100 & 2070 & 2050 \\
\hline
\end{tabular}

Thus, the amount of necessary flour for an experimental batch of bread weighing 1 ton is not counted on the yield of bread $138 \%$, but with an increase of $8.7 \%$, i.e. by $146.7 \%$ : (production / output) x $100=(1000 \mathrm{~kg} / 146.7) \mathrm{x}$ $100 \%=681.7 \mathrm{~kg}$.

We determine the cost of the 1 st grade flour used in control with an average market value of 110 tenge $1 \mathrm{~kg}$ (as of September 2019) for the production of 1 ton of bread:

The cost of flour for a control batch $=$ price of flour $\mathrm{x}$ amount of flour $=110$ tenge $\mathrm{x} 724.6 \mathrm{~kg}=79706$ tenge.

The cost of flour for an experimental batch $=$ price of flour $\mathrm{x}$ amount of flour $=110 \times 681.7 \mathrm{~kg}=74987.0$ tenge.

\section{Calculation of additional raw materials}

The consumption of additional raw materials was calculated according to the norms of flour.

In the control batch, the additional raw materials are pressed salt and yeast, and in the experimental batch another $0.5 \%$ of the mass of flour is included in the additional raw materials.

The required amount of salt in the control batch $=($ amount of flour $\mathrm{x}$ normal salt $) / 100=(724.6 \mathrm{x} 1.5 \%) / 100=$ $10.869 \mathrm{~kg}$.

The average cost of table salt in Almaty is 35 tenge $/ \mathrm{kg}$. The total cost of salt for the production of 1 ton of bread will be 380.4 in the control, for the experimental batch $=$ (amount of flour x normal salt) $/ 100=(681.7 \times 1.5 \%) /$ $100=10.226 \mathrm{~kg}$ or 357.9 , respectively (table 2 ).

The amount of pressed yeast required for the control and experimental batch of $2.5 \%$ or $18.115 \mathrm{~kg}$ and $17.04 \mathrm{~kg}$, respectively. With the average wholesale cost of pressed yeast in Almaty being 450 tenge / $\mathrm{kg}$, the cost of the required yeast for the production of the control lot will be 8152 tenge, and for the experimental one - 7668 tenge. The amount of pumpkin pectin recommended with an optimal dosage of $0.5 \%$ by weight of flour in an experimental batch will be $681.7 \times 0.005=3.41 \mathrm{~kg}$, and the cost of pectin on September 1 is about 6000 tenge $\mathrm{x}$ $3.41 \mathrm{~kg}=20460$ tenge (table 2). 
ISSN 2345-0282 (online) http://jssidoi.org/jesi/

2020 Volume 7 Number 4 (June)

http://doi.org/10.9770/jesi.2020.7.4(40)

\section{Fuel and electricity consumption:}

The cost of the fuelexpenses (gas), electricity and water for kneading and baking the dough were taken according to the actual data of the bakery of "Almatynan" LLP, which for the production of 1 ton of bread are: natural gas about 1522 tenge, electricity about 1683 tenge, water consumption 136 tenge (from costing of the enterprise).

The amount of costs for electricity and fuel in table 2 are indicated with a decrease of $20 \%$ due to a reduction in the time for fermentation and baking bread with pumpkin pectin, respectively, while the cost of water increased by 3-4 tenge, because 180-200 kg more water was spent in the experimental batch than in the control one.

Table 2 presents the calculation of the cost of 1 ton of control and experimental lots (with pumpkin pectin $0.5 \%$ by weight of flour) of bread.

Table 2. Calculation of production costs of 1 ton of control and experimental batch of bread enriched with pumpkin pectin (according to the company)

\begin{tabular}{|c|c|c|c|c|c|c|}
\hline \multirow[t]{2}{*}{ Indicator } & \multirow[t]{2}{*}{$\begin{array}{l}\text { Quantityper } \\
1 \mathrm{t}, \mathrm{kg}\end{array}$} & \multirow{2}{*}{$\begin{array}{l}\text { Pricefor } \\
1 \quad \mathrm{~kg} \text {, } \\
\text { tenge }\end{array}$} & \multicolumn{2}{|c|}{ Amount per 1 ton of bread, tenge } & \multicolumn{2}{|c|}{$\begin{array}{l}\text { Amount per loaf weighing } 0.5 \mathrm{~kg} \text {, } \\
\text { tenge }\end{array}$} \\
\hline & & & control & experienced & control & experienced \\
\hline $\begin{array}{l}\text { The main raw materials, } \\
\text { flour } 1 \mathrm{~s}\end{array}$ & 724,6 & 110,0 & 79706 & 74987 & 39,9 & 37,5 \\
\hline \multicolumn{7}{|l|}{ Additionalrawmaterials: } \\
\hline Salt & 0,869 & 5,0 & 380,4 & 357,9 & 1,9 & 0,18 \\
\hline Pressedyeast & 8,115 & 450,0 & 8152 & 7668 & 4,48 & 3.8 \\
\hline Pumpkinpectin & - & - & - & 20460 & - & 10,23 \\
\hline Water & 0,40 & 36 & 54,4 & 57,12 & 0,029 & 0,03 \\
\hline Pieceworkwage & & & 3859 & 3859 & 2,1 & 1,9 \\
\hline Socialtax & & & 444 & 444 & 0,2 & 0,2 \\
\hline Totaldirectcosts & & & 92595,8 & 107833,2 & 48,6 & 53,8 \\
\hline Electricpower & & & 1683 & 1346,4 & 0,9 & 0,67 \\
\hline Naturalgas & & & 1522 & 1217,6 & 0,84 & 0,61 \\
\hline Totalconditionallyvariablecosts & & & 3205 & $\begin{array}{l}\mathbf{2 5 6 4} \\
2576\end{array}$ & 1,8 & $\begin{array}{l}1,42 \\
1,28\end{array}$ \\
\hline Salaryofdrivers & & & 6832 & 6832 & 3,76 & 3,76 \\
\hline Fuelandlubricantsexpenses & & & 1557 & 1557 & 0,9 & 0,9 \\
\hline Fixedcosts & & & 8389 & 8389 & 4,61 & 4,61 \\
\hline Totalcost & & & 104189,8 & 118786,2 & 55,1 & 59,7 \\
\hline
\end{tabular}

The production costs of 1 ton of bread enriched with pumpkin pectin in an amount of $0.5 \%$ exceeded $14,596.4$ tenge or $14.0 \%$, compared with the control batch without pectin. When calculating the consumption in the experimental batch per 1 roll of molded bread weighing $0.5 \mathrm{~kg}$, the prime cost was higher by $8.3 \%$ and amounted to 59.7 tenge, in the control batch -55.1 tenge, respectively.

\section{The calculation of production costs for the production of confiture enriched with pumpkin pectin}

In the conditions of the fruit and vegetable cannery of "SDiK" LLP, production tests were carried out to develop confiture with pumpkin pectin. These products on organoleptic and physical-chemical indicators met the requirements of technical conditions, the results are issued by the corresponding act approved by "SDiK" LLP.

Referring to the fact that the pumpkin pectin isolated by us is classified as low-esterified ( $\mathrm{CE}=39-43 \%)$, has a low gelling ability, but a high complex-forming ability, we developed a technology for preparing confiture using crushed pieces of pumpkin and pumpkin pectin. 
On the basis of production research, the economic efficiency of the production of confiture with pumpkin pectin was determined. Confiture prices were calculated according to the methodological materials "Cost of production and product shipment". The cost calculation is shown in table 3. The cost of the resulting confiture is $12 \%$ cheaper than the control sample due to savings: the power consumption in the control was 1.75 tenge and 1.31 tenge with pumpkin pectin due to a decrease in the cooking time; sugar 66.2 tenge in control and 57.1 tenge with pumpkin pectin. The boiling process was reduced by $25 \%$ for $15-20$ minutes, instead of 25-30 minutes according to the classical scheme, because recommendations for boiling confiture are mainly based on berries, which have a dense, undisturbed skin, and sliced pieces of pumpkin do not have a skin, so the boiling process has been reduced.

Table 3. Calculation of the cost of $1 \mathrm{~kg}$ of "Pumpkin"confiture at "SDiK" LLP

\begin{tabular}{|c|c|c|c|c|c|c|c|}
\hline \multirow{3}{*}{$\begin{array}{l}\text { Name of raw materials and } \\
\text { costs }\end{array}$} & \multicolumn{4}{|c|}{ Rawmaterialconsumption } & \multirow{3}{*}{$\begin{array}{l}\text { Price for } 1 \mathrm{~kg} \\
\text { of } \\
\text { materials, raw } \\
\text { tenge }\end{array}$} & \multicolumn{2}{|c|}{ Cost of $1 \mathrm{~kg}$ of confiture, tenge } \\
\hline & \multicolumn{2}{|c|}{ control } & \multicolumn{2}{|c|}{ withpumpkinpectin } & & \multirow[t]{2}{*}{ control } & \multirow{2}{*}{$\begin{array}{l}\text { withpumpkinpectin } \\
1,0 \%\end{array}$} \\
\hline & $\%$ & gram & $\%$ & gram & & & \\
\hline Sugar & 55,0 & 550 & 47,5 & 475 & 185,0 & 101,8 & 87,9 \\
\hline Sliced pumpkin & 42,5 & 425 & 50 & 500 & 70 & 29,8 & 35,0 \\
\hline Agar-agar & 1,0 & 10 & - & - & 6500,0 & 65,0 & - \\
\hline Pumpkin pectin & - & - & 1,0 & 10 & 6000 & - & 60,0 \\
\hline Lemon acid & 1,0 & 10 & 1,0 & 10 & 560,0 & 5,6 & 5,6 \\
\hline Cinnamon & 0,5 & 5 & 0,5 & 5 & 1500,0 & 7,5 & 7,5 \\
\hline \multicolumn{8}{|c|}{ Data on the costs of the fruit and vegetable factory "SDiK" LLP } \\
\hline Boilingpower & - & - & - & - & - & 2,0 & 1,5 \\
\hline Cold water, sewer & - & - & - & - & - & 0,44 & 0,44 \\
\hline $\begin{array}{l}\text { Hot water, heating, fuel } \\
\text { and lubricants }\end{array}$ & - & - & - & - & - & 13,0 & 13,0 \\
\hline Salary & - & - & - & - & - & 20,0 & 20,0 \\
\hline Total cost: & - & - & - & - & - & 245,1 & 230,9 \\
\hline
\end{tabular}

Thus, the calculations showed that the use of pumpkin pectin in the production of bakery products is not costeffective. However, in modern conditions, for business to realize their economic goals, it is not enough to focus only on making a profit. Long-term development involves a move in the direction of social responsibility, which not only creates a positive image of the company, but also expands the market.

It is necessary to take into account that the social effect also contributes to the increase of economic efficiency, since "improving the health of the population provides savings on the payment of temporary disability benefits, disability pensions." The social results can be improved public health, increased life expectancy due to the consumption of pectin-containing foods that reduce the negative impact of increased environmental pollution. When the social effect in money cannot be measured (since many social processes cannot be completely formalized), many social results can be measured with varying degrees of fidelity, which allows companies to evaluate the usefulness of their actions to the social environment (Sindyashkina, 2010). In general, an increase in the number of positive social effects contributes to intensive economic growth and the strengthening of the serious competitive advantages of the national economy. 


\section{ENTREPRENEURSHIP AND SUSTAINABILITY ISSUES}

ISSN 2345-0282 (online) http://jssidoi.org/jesi/

2020 Volume 7 Number 4 (June)

http://doi.org/10.9770/jesi.2020.7.4(40)

\section{Conclusions}

1. The social efficiency of the production of developed pectin-containing products is determined by expanding the range of functional food products with improved consumer properties.

2. The enrichment of bread with pumpkin pectin $(0.5 \%)$ increases the yield of bread by $8.7 \%$, which is importan in solving the problem of ensuring food security of the country. However, the cost of producing 1 ton of bread enriched with pumpkin pectin in an amount of $0.5 \%$, exceeded by $14.0 \%$, compared with the control batch without pectin.

3. The use of pectins allows you to increase the shelf life of safe bread, resulting in reduced return of products from trade organizations back to production, which is economically beneficial for the baking industry.

4. The optimal dosage of pumpkin pectin in the composition of the jelly product - confiture in the amount of $1.0 \%$ was established. The cost of $1 \mathrm{~kg}$ of confiture with pumpkin pectin amounted to 230.9 tenge, which is $9 \%$ lower than the cost of the control sample due to the reduction in boiling time, which reduced the energy consumption by $25 \%$ and the amount of sugar by $7.5 \%$.

\section{References}

Alibaeva, B.N., Omarova, A.S., Tsitsurin, V.I., Esdaulet, B.K., Adambekova, M.R., Seralin E.B. 2015. The content of heavy metals in the body as an indicator of the environmental load of places of residence and the possibility of effective correction of the health of the population of a modern metropolis on the example of Almaty. International Journal of Experimental Education: Publishing House Academy of Natural History (Penza) ISSN: 1996-3947. 2, 70-75.

Almaty's contribution to food production in the country. Foodindustry.kz, May 29, 2019 https://foodindustry.kz/vklad-almaty-vproizvodstvo-produktov-pitaniya-v-strane/

AlmovaI, Kh., Beriketov, A.S., Inarokova, A.M., Sabanchieva, J.Kh. 2014. The experience of using pectin in diseases associated with harmful factors of production. International Journal of Applied and Basic Research, 5(2), 62-65.

Azimova, S. T., Kizatova, M.J., Akhmetova, S.O., Donchenko, L.V., Admayeva A.M. 2017. Towards food security through application of novel scientific findings. Journal of Security and Sustainability Issues, 6(4), 719-729.

Azimova, S.T., Aidossov, A.A., Kizatova, M.Zh., Zaurbekova, G.N. 2016. Development of the information system for monitoring, model prediction of changes in the quality of the environment and public health indicators of industrial region, studying the anatomical composition of pumpkins from useful components of flora for human, No. 2 for 2016 year, Materials of conferences (Munich, Germany, 16 November 2016).

Azimova, S.T., Kizatova, M.Zh., Alibaeva, B.N., Nabieva, Zh.S., Dyusembaeva, B.K. 2017. The effect of pumpkin pectin on the quality and safe shelf life of bread. Bulletin of the Almaty Technological University, 4, 89-93.

Babich, O., Dyshlyuk, L., Noskova, S., Sukhikh, S., Prosekov, A., Ivanova, S., Pavsky, V. 2017. In vivo study of medical and biological properties of functional bakery products with the addition of pumpkin flour. Bioactive Carbohydrates and Dietary Fiber, $12,20-24$.

Belousova, A.I., Donchenko, L.V. 2019. Automation of technological process of obtaining pectin. E3S Web of Conferences Web Conf. Volume 126, 2019 International Conference on Current Trends in Manufacturing Technologies and Equipment (ICMTMTE 2019)

Donchenko, L. V. 2000. Technology of pectins and pectin products / L. V. Donchenko: textbook. M.: DeLi, 255 p.

Ecology and health of the nation. Collection 7. 3rd edition, revised. and add. - Karaganda: Publishing house of the Karaganda State Technical University, 2016, 109 p.

Gavrilenkov, A. M. 2006. Ecological safety of food production. St. Petersburg: Giord, 272 p. 


\section{ENTREPRENEURSHIP AND SUSTAINABILITY ISSUES}

ISSN 2345-0282 (online) http://jssidoi.org/jesi/

2020 Volume 7 Number 4 (June)

http://doi.org/10.9770/jesi.2020.7.4(40)

Grassino, A.N., Barba, F.J., Brnčić, M., Lorenzo, J.M., Lucini, L., Brnčić, S.R. 2018. Analytical tools used for the identification and quantification of pectin extracted from plant food matrices, wastes and by-products: A review. Food Chemistry, 266(15), 47-55.

Janabi, M., Rad, A. H. A., Esteri, S.H. 2017. Investigating the effect of different levels of pectin on tissue profile, color and sensory evaluation of watermelon marmalade. Journal of Innovation in Food Science and Technology, 9(1). Pe51-Pe59 ref. 19.

Kostyuk, T.A. 2005. Development of technological solutions for the use of watermelon pectin in the production of bakery products. Technical Science: M., 23 p.

Lara-Espinoza, C., Carvajal-Millán, E., Balandrán-Quintana, R., López-Franco, Y., Rascón-Chu, A. 2018. Pectin and Pectin-Based Composite Materials: Beyond Food Texture. Molecules, 23, 942-961. https://doi.org/10.3390/molecules23040942

Martins, Z., Pinho, O., Ferreira, I. 2017. Food industry by-products used as functional ingredients of bakery products. Trends in Food Science \& Technology, 67, 106-128.

Melnikov, A.B., Mikhailushkin, P.V. Poltarykhin, A.L., Dibrova, Z.N. 2019. Economic Aspects of Addressing Food Security: Case Study, Entrepreneurship and Sustainability, 7(1), 595-602. https://doi.org/10.9770/jesi.2019.7.1(41)

Murzahmetova, M.K., Tayeva, A.M., Nabiyeva, Zh.S., Baimaganbetova, G.B., Kizatova, M.Zh., Kulazhanov, K.S., Vitavskaya, A.V. 2015. Antioxidant Activity of Breads. Research journal of Pharmaceutical. Biological and Chemical Sciences. ISSN: 0975-8585, 6(3). 10201025 .

Moumen, Z., El Idrissi, N.E.A., Tvaronavičienè, M., Lahrach, A. 2019. Water security and sustainable development. Insights into Regional Development, 1(4), 301-317. https://doi.org/10.9770/ird.2019.1.4(2)

Noreen, A., Nazli, Z., Akram, Zh., Rasul, I., Mansha, A., Yaqoob, N., Iqbal, R., Tabasum, S., Zuber, M., Zia K. 2017. Pectins functionalized biomaterials; a new viable approach for biomedical applications: A review. International Journal of Biological Macromolecules, 101, 254-272. https://doi.org/10.1016/j.ijbiomac.2017.03.029

Sindyashkina, E.N. 2010. Issues of assessing the types of social effect in the implementation of investment projects. Problems of Forecasting, 1, 140-147.

\section{Acknowledgements}

The research was carried out within the framework of the performance-based grant budgeting for 2018-2020 by the Ministry of Education and Science of the Republic of Kazakhstan under the Program "Creating Healthy Foods with Functional Orientation Based on Agricultural Raw Materials” 
Maigul Zhalelovna KIZATOVA

ORCHID ID: orcid.org/0000-0002-6481-7410

Sanavar Tuglukovna AZIMOVA

ORCHID ID: orcid.org/0000-0002-8992-8889

Galiya Kuandykovna ISKAKOVA

ORCHID ID: orcid.org/ 0000-0002-2077-8755

Farrukh Abdigapurovich MAKHMUDOV

ORCHID ID: 0000-0002-7791-1588

\section{Almira Anuarbekovna BEKTURGANOVA \\ ORCID ID: orcid.org/0000-0002-3451-2587}

Register for an ORCID ID:

https://orcid.org/register

\footnotetext{
Copyright (C) 2020 by author(s) and VsI Entrepreneurship and Sustainability Center

This work is licensed under the Creative Commons Attribution International License (CC BY).

http://creativecommons.org/licenses/by/4.0/

cC) (i) Open Access
} 